\title{
FREEDOM AND OPPRESSION OF SLAVES IN THE EIGHTEENTH-CENTURY CARIBBEAN*
}

\author{
Arthur L. StinchCOMBE \\ Northwestern University
}

Characteristics of two different social systems, island government and the particular master-slave relationship, jointly determined the degree of freedom of slaves in the Caribbean in the late eighteenth century. The degree to which an island was "a slave society" depended on the dominance of sugar cane in the island economy, and whether planters were internally well-organized and were powerful in the empire government. The Bahamas and Santo Domingo (the Dominican Republic) had low planter power on both criteria; Barbados and Antigua had high on both. Within a slave society, the degree to which a slave was treated like a free man or woman was determined by the slave owner's need for the slave's consent and enthusiasm as a trusted agent. This varied within islands: Slave pearl divers, dock workers, fishermen, mistresses, hucksters, soldiers, or cowboys tended to be nearly free when slaves and were likely to be formally or informally set free, even if island governments strongly limited their freedom.

$N_{0}$ ociologists have had great trouble developing a sociology of freedom and of its opposite, slavery. Orlando Patterson started with the sociology of slavery (1967) and developed freedom as its opposite (1991). I follow Patterson in starting my investigations in the Caribbean at the height of slave society ${ }^{1}$ in the late eighteenth century, before "amelioration" or "emancipation."

But I do not follow Patterson's mature work (1991). He shows how the history of

${ }^{*}$ Direct correspondence to Arthur L. Stinchcombe, Sociology, Northwestern University, Evanston IL 60208. Terry Boswell, Rogers Brubaker, Christopher Jencks, Mindie LazarusBlack, John Markoff, and Charles Tilly commented on previous versions of this paper. Concentrating the historical information into tables, thus making room for the argument, was suggested by Carol A. Heimer. Much of the historical information appears in an appendix available from the author, which tells how the tables were generated. Roughly one-fourth of the research and writing was supported by Heimer's summer salary, one-fourth by a Guggenheim Foundation fellowship, and half by paid leave from the College of Arts and Sciences of Northwestern University. The support of the Willima and Marion Haas Fund for the map is gratefully acknowledged.

${ }^{1}$ Goveia (1980 [1965]:vii), defined this term in a way slightly different from mine, but the main island she studied, Antigua, was one of the most "slave society" islands in the late eighteenth century by the definition I am using here.

the idea of freedom was shaped by the social and normative experience of its opposite, slavery. I treat freedom or liberty as the high end of a continuous empirical variable in the eighteenth-century Caribbean, a variable whose low end is slavery in the ideal-typical sense. In particular, I study how the restriction of the possibilities among which slaves could choose was greater in some slave islands than in others, and less among slaves serving some functions for their masters that required slave loyalty, enthusiasm, or discretion.

I define freedom as a set of liberties. As the argument develops, it will be clear that many of the decisions slaves in fact took freely were not protected by law. John R. Commons's (1924:92-100;11-46) definition of liberties enables me to conceive of slaves' freedom as a variable made up of the liberties they in fact enjoyed, whether or not they were defended in the law. Because of the way restrictions on slave liberties were defined, low slave freedom means high liberty of the slave owner to do as he or she likes with the slave.

By a liberty, Commons means a decision that someone can take even if the consequences damage or help others, so the decision may mean a loss to one other, but a gain to a third person. For example, Spanish law provided that if slaves of different owners married, one or the other owner had to sell 
his or her slave so that the marriage could exist. This created a slave legal liberty, but in fact there was often no practical possibility for such unions to be created (e.g., owners tended to import males) and no real way for slaves to call on the law. The legal fact shows that more legal liberties existed at the time in Spanish colonies than in British colonies, but the practical fact meant that on sugar plantations in Cuba (a Spanish colony) slaves were too dominated to marry, while in Trinidad (a Spanish colony that became British with Spanish law in 1800) many could marry.

The reason the social structural answer to the practical existence of liberties disagrees with the legal answer depends on Commons's observation that a liberty creates an exposure of others to the different consequences of different choices by the free person. When the person exposed to the consequences likes them (or can contract to get the right decision for a price), all goes well. But when a practical slave liberty damages masters, laws may be tightened, informal sanctions within the practical liberties of slave owners may be brought to bear, or male African slaves only may be imported.

Freedom, then, is here defined as a latent, usually unobservable, conceptual variable describing the sum of practical liberties of a slave life, decisions that slaves could in fact take, rather than the sum of legally defended slave liberties (which were very minimal indeed). Every practical existence of a slave liberty was a limitation on the liberty of the slave owner to do as he or she liked with the slave. We can look for the indicators of freedom defined in this way, its legal and social causes, interpret the motives of slaves to seek more freedom by means other than laws, and perhaps ultimately reconstruct the life experience of the difference between legal slavery and legal freedom when slaves were manumitted or emancipated. The definition then is a sum of practically available liberties, including, in particular, the social capacity to get others to suffer the consequences of the practical freedom of slaves to decide.

\section{BACKGROUND}

The conception of slavery as a dichotomous legal status represented in laws, and contrasted to a status of freedom, is of course irrelevant to my purpose of describing and explaining variations among slave islands and among slaves within islands. But most comparative work on slavery (e.g., Tannenbaum 1946; Klein 1967; Goveia [1965] 1980; or Patterson 1991) treats the elements of slavery as dichotomies in the law, a list of various things that are permitted or forbidden to slaves that are permitted or forbidden to free men (or to proletarians, serfs, subfeudatories, freeholders, nobles, free women, or other contrast groups). The dichotomy between slave and free is then constituted by its subdichotomies of legal freedoms or constraints, and slave systems can then be compared by the components that constitute their overall contrast between slave and free.

As Patterson pointed out in his magnum opus (1991), such a pattern of contrasts between slaves (of various kinds) and free people (of various kinds) constitutes a particular society's definition of freedom; it is what all nonslaves hold in common. A particularly crucial aspect of freedom so conceived is the right to call upon courts or other authorities, more or less separate from one's owner or superior, to defend one's rights, or to defend one's practical freedom by using other more or less legal liberties, such as emigration, rebellion, or the right to duel.

The dispute between Tannenbaum (1946) and Klein (1967) on the one hand and Moreno Fraginals ([1964] 1976) on the other, for example, provides a contrast between such conceptions of how to analyze slavery, legal dichotomies versus daily practice. The central question Moreno Fraginals asks is how far variations in legal rights between Spanish and English colonies (here especially Cuba and Virginia) influenced the realization of slavery found on the Cuban ingenios (in Spanish the word for plantations refers to the sugar mill rather than the planted fields; in both Spanish and English colonies, sugar plantations had both) so as to make it different from that in Virginia. Moreno Fraginals argued that the probability of concrete oppression is better predicted by the demands of sugar plantations and the drive for cheap labor through legal and illegal coercion of slaves than by differences in legal freedoms or in the possibility of appeal to the church authorities. In contrast, Williams ([1944] 1964:6-7) argued that free la- 
bor was cheaper if already there because it was more productive-but it would be more expensive to move, and this would imply that coercion of the slaves was inefficient once they were in the Caribbean. Broadly, my approach agrees with that of Moreno Fraginals as against Klein and the others, that economic dominance of sugar and planter power determine the oppressiveness of slavery. But I argue that this gives a different prediction for late eighteenth-century Cuba as a whole than he found on the nineteenth-century ingenios (these had less than half of Cuban slaves in the nineteenth century, and even less in the late eighteenth century).

My conception of the degree of freedom of slaves is the inverse of the probability of coercive limitation in daily life of many rights less often interfered with among free men. Here differences in the probability of coercive limitation of rights in everyday life define the difference between slave and free, and those probability differences can be large or small in different societies. Free women of the eighteenth century, by this definition, were less free than free men, but freer than slave men or women. That is, free women could make more decisions about daily life without coercive interference than could slaves.

One main argument here is that the degree to which law and political authority ferreted out incipient slave liberties or patches of freedom and relentlessly invented laws to suppress them, was itself shaped by the determinants of planter power. Thus, in some sense, the effectiveness of the law in depriving slaves of liberty on a daily basis was another effect of the same cause as frequent intervention by the planter in slave daily life within that law. This is because slave law was a dynamic achievement of planter power, just as the concrete elimination of choice and appeal to the courts or police for slaves was. Sugar plantations of long duration on more self-governing islands caused both legal and daily life dynamics and so slaves were less free on sugar islands.

To be more explicit about the implications of this for the empirical argument, the dependent variable explained in Tables 1 and 2 that follow is not explicitly measured. As explained in more detail in the theory here and in an appendix on the Constitution of the
Data, the dependent variable is an estimate of how many possible liberties of slaves the government of an island devotes itself to limiting. (The appendix is not shown here, but is available on request from the author-hereafter it is referred to as "Author's Appendix.") The basic thing being protected by such a government is the liberty of the planter to do whatever he or she wants with a slave. The ingenuity devoted to making governmental provisions against all liberties of slaves that might interfere with such liberties of planters is the implicit explicandum of the tables.

A melange of observations went into my judgment of how much island colonial governments limited slaves' freedom (which, to anticipate, is the unobserved dependent variable in Table 2): interference with slave marriage, not allowing slaves provision grounds, making manumission (the release of a slave from bondage by the owner) difficult, forbidding slaves to sell things, requiring slaves off the plantation to carry a permission from the master, forbidding missionaries from converting slaves, regulating singing, prohibiting magic, prohibiting sleeping in houses of nonslave relatives, prohibiting the naming of slave children after their White father-in a deep slave society the list goes on and on. But I could only form an impressionistic diagnosis of how active the government was in devoting itself to such regulation. Data on any one of the items on this operationalization of the degree to which an island had a slave society government was quite likely to be missing for half or more of the islands.

Deliberate institutional action to restrict choices varied among island governments. For example, the Spanish colonial governments of Santo Domingo (the Domincan Republic) and Puerto Rico and the Dutch government of Curaçao spent almost no effort to make sure slaves had no choices, no liberties, and made some effort to restrict the liberties of planters. The government of Barbados, in contrast, did little else but make sure that slaves could choose almost nothing, and that planters could therefore choose all aspects of slaves' lives. I will call Barbados in the eighteenth century "more of a slave society" than Puerto Rico, Santo Domingo, and Curaçao, because although all had slaves, the latter did not spend much governmental effort making sure they could not choose anything. Thus 
the first dimension I use to discuss the "freedom" variable among slaves (ranging from slave to free) is the degree to which their island government devoted itself to their "unfreedom." The best measure of freedoms granted by individual masters-whether or not those masters granted legal manumission (termination of bondage)-is not at all a good measure of this inter-island variation. (For reasons, see the Author's Appendix.)

But even in Barbados, some slave owners gave some of their slaves their freedom. The enthusiasm of slaves for being free rather than slave, even though there were many restrictions on the possibilities of the "free colored" Barbadians, ${ }^{2}$ shows that they thought free was better than slave. And there is every sort of evidence that slaves in the categories most often freed (e.g., domestic servants, soldiers, skilled workers, mistresses) were treated more like free people, even before they were freed. The owner, as well as the society, could restrict or expand the possibilities among which slaves could choose, and of course the owner's free discretion of which slaves should have more liberties was rarely legally specified or recorded. And the way they expanded them in daily life in Barbados, or failed to restrict them in Curaçao, formed regular social patterns that can be explained.

This informal system of slave owners providing some slaves rights to choose, even ultimately sometimes formal legal freedom, is thus another form of variation from slave to free among formal slaves. In the worst case, an owner's slave mistress in Spanish colonies

\footnotetext{
${ }^{2}$ The term "colored" was generally used in the sources for this paper to designate persons of mixed African and European ancestry. Particularly when referring to slaves, "colored" meant "of mixed ancestry." However, the term "free colored" was used to designate any former slave freed during a period when there was still slavery, whether the slave was of mixed or exclusively African ancestry. As I explain in the argument connected to Table 3, there was a correlation between color and freedom, with those having European ancestry being more likely to be manumitted-but that correlation was much less than 1.0. I cannot be more precise in distinguishing ancestry and condition of servitude than the sources I use. It is a separate question, not analyzed here, why Whites made little social distinction by color among free people with African ancestry.
}

could be tortured. A wonderful description of an awful case in Trinidad after 1800 that had British authorities applying Spanish law, is Naipaul's "Apply the Torture" ([1969] 1984: 182-221). But the whole context of the case shows that this slave, a White man's mistress, had a great deal of effective freedom. In fact, owners' mistresses and their children tended to end up free rather than tortured, and moderately often ended up rich (e.g., Cauna 1987:53-56). The extreme case for labor was for the slave to work under the whip to the limits of endurance in holing for the young sugar plant. In fact, some slaves in Spanish colonies (in the eighteenth century the main ones were Trinidad, Cuba, Santo Domingo, and Puerto Rico) were paid wages (Boin and Serrule Ramúe [1979] 1985:61, 63). The right to inherit freedom from one's slave mother and part of the estate from one's planter father was surely a step toward freedom for a person born a slave, and the right to spend one's own wages is generally taken as a test of free labor. So the worst case under the law was sometimes not the average case.

Holt's (1992) study of the emancipation of slaves in Jamaica has an intellectual strategy comparable to mine here. He showed that the political process of emancipation restricted the choices of ex-slaves so they would work for planters "freely" for low wages. In part, this required taking away the rights to houses they had built and subsistence plots for which they had broken ground in their "free time" as slaves, so that they would have to earn them back by working on the plantation. But there was no agitation among Blacks to recreate slavery so they could claim houses and subsistence plots. That is, Holt studied one island as it changed from a moderately oppressive slave society to a "free society ruled by a planter legislature"; Holt's main point was that this latter society was not very free.

I have chosen instead to study cross-island variation between about 1750 and 1790 . The intensity of government concern to preserve slaves' lack of freedom varied from one island to another. In many ways, Blacks on Dutch Curaçao or Aruba were freer under slavery in the mid-nineteenth century than were the emancipated slaves in Jamaica that Holt studied. A commercial aristocracy did 
not need gang labor in the fields-it needed agents to help them run their businesses and their homes. They did not devote their government to depriving slaves of freedom, nor did they devote their daily personal dealings with their slaves to restricting slaves' choices.

By specifying the causes of variations among islands in the degree to which planter power could create a slave society, I describe one main force that restricted the choices of slaves. By specifying when masters found it to their advantage to leave some liberties in the hands of individual slaves, sometimes manumitting them (freeing them from bondage)-that is, by specifying when slave owners, though legally permitted, did not push slave lack of freedom to its utmost-I describe informal transactions that increased the possible choices available to slaves and explain the variation within islands in the degree of freedom that slaves experienced.

I argue that this tack toward understanding variations in freedom within islands, as well as between them, helps avoid defining freedom, or slavery, by its essence. Defining things by their essences is always troublesome in an explanatory science. So defining slavery by its uttermost extremity, by the fact, for example, that rape of slaves by their owners usually could not be punished, does not explain why mistresses of White men were disproportionately colored, were sometimes given their freedom, and sometimes inherited part of their lover's estate.

Nor does the extremity of hard work under the lash in holing a field to plant sugar cane explain why skilled workers on plantations or dock workers in towns were more often given their freedom, more often made contracts for their services with people other than their owners, and more often rented houses from urban landlords and bought their own food than did slaves on sugar plantations. Worst case scenarios tell us whether we are in a slave society, perhaps, but they do not tell us about the expansion and contraction of the space of choice in the lives of individual slaves. Such scenarios may be good guides to the macrosociology of freedom, to whether there has been governmental care on a given island to make sure that slave owners are not forbidden to push their liberties with slaves to the extreme, but they are not a good guide to the informal part of the sociology of slavery and freedom.

I define the degree to which an island was a "slave society" as the degree to which the island government devoted itself exclusively to making the liberties of the planters in their property unlimited, and had the powers to do a good job of that. This, then, is the first determinant of how oppressed a slave was. I argue that the main determinants of the degree to which an island limited slave liberties (to maximize owners' liberties to use slaves as they pleased) were: the degree to which an island was a sugar island (sugar planters were the largest and most demanding users of slave labor); the degree of social and political organization of planters (better organized planters could better build the island society around oppressive sugar slavery); and the political place of the planters in island government and of the island government in the empire (the more powers local planter government had, the less limited it was in building a slave society).

Conceiving of planter institutional power as the institutionalization of a planter liberty over his or her property means that the higher slave owner power is, the more the owner can treat a slave any way he or she pleases. ${ }^{3}$ We now are inclined to moral judgment of the slave system by what was the worst that could happen to the slaves, and rightly so. But that was not the way a slave had to look at it in order to try to live a decent life within that system. In particular, planter owners could supervise slaves closely in gang labor in the fields and make no promises, or they could negotiate contracts with their slaves, or even set them free-and which the owner chose mattered a lot to the slave.

The very thing that made slave owners powerful-the existence of a slave society-made what they wanted to do the main determinant of what happened to the slave. If we study who it was that the planters set free as the extreme manifestation of owner liberty, we find systematic and powerful patterns in how much the "deals" slave owners made with their slaves resembled those they made with free people, including

\footnotetext{
${ }^{3}$ Women treated their slaves (mostly domestic slaves) much differently than men treated their slaves (mostly field hands).
} 


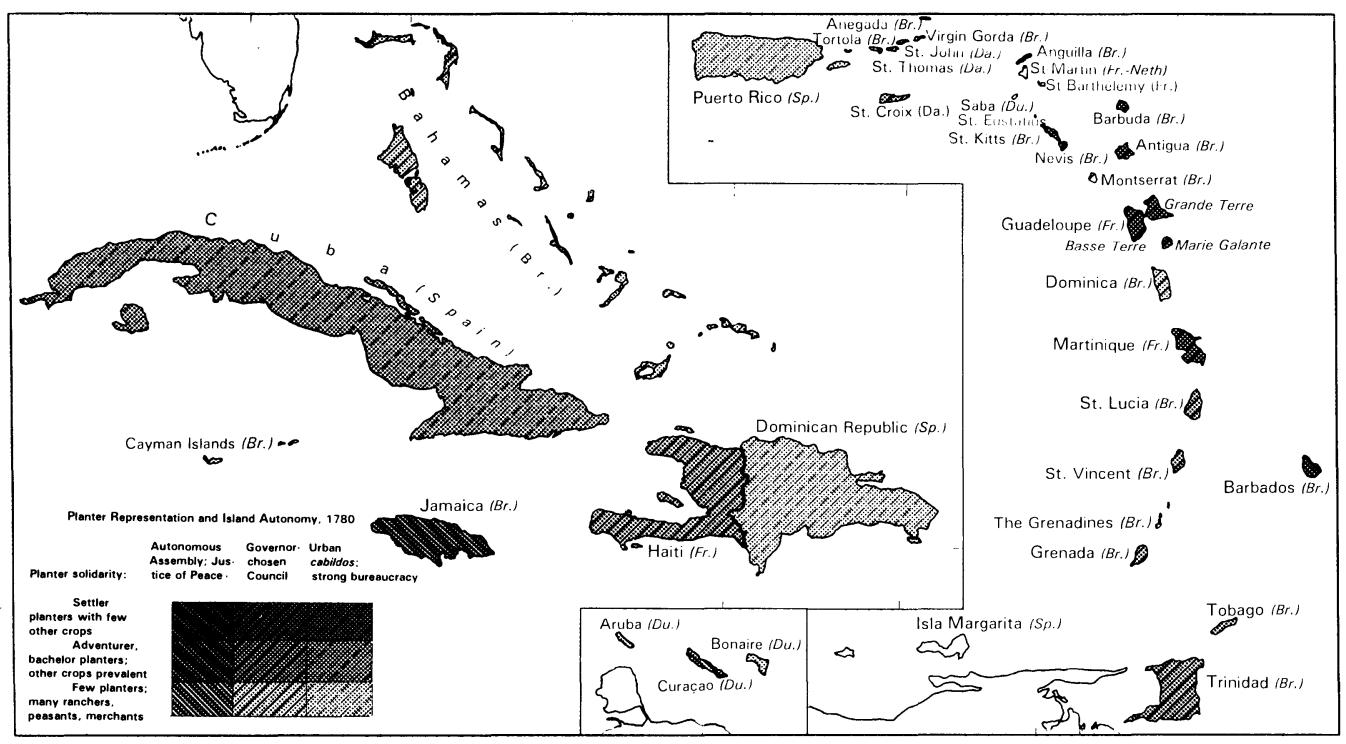

Figure 1. The Caribbean Islands in the Late Eighteenth Century: Planter Representation and Island Autonomy

Note: Dominance of sugar planters is indicated by the shading, and empire on the island toward the end of the century by abbreviations. Trinidad's government was Spanish, its planters mostly French, and by 1800 it became British with Spanish law still valid; I have chosen to call it British on the map and have shaded it according to the planter dominance in the English period. Isla Margarita did not have a separate island government. The map was prepared by Prof. John C. Hudson, Northwestern University.

"deals" that set the slaves free, that extinguished the relevant slave owners' liberties. Slave societies probably varied in their manumission rates, but (as explained in the Author's Appendix) available data make manumission rates very difficult to determine. But the will of an individual slave owner on an island with a given intensity of slave society determined which slaves on that island would be freer; differential manumission rates of groups within islands can indicate that.

The core bourgeois liberty is the freedom to alienate property, to truck, barter, and exchange. The distinctive thing about slaves as a type of property is that one can alienate them to themselves, can give them the liberties to decide what to do. Hence manumission, the individual granting of freedom, is a sensitive tracer of which slaves were most treated as free people.

My argument is that the central determinant of within-island variation among owners in treating slaves more like they were free was the owner wanting the slave to be a responsible agent in unsupervised services or work, work involving care or enthusiasm or risk to the worker, or work requiring loyalty that could be easily betrayed. Thus, when the slave owner wanted trustworthy agency by slaves, he or she treated them as if they were free, as if they had rights, and in the extreme gave them rights.

\section{EXPLAINING INTER-ISLAND VARIATION IN SLAVERY: SUGAR CANE, PLANTER DOMINANCE, AND ISLAND AUTONOMY}

In Tables 1 and 2, I apply the core variables of my analysis of the degree to which an island was a slave society to most of the Caribbean islands. The units of analysis in Table 1 are "islands," in the geographical and economic sense, unified bounded economic and geographical systems in the eighteenth century. (See Figure 1.) As explained in the Author's Appendix, what are conventionally called islands are in fact usually "clouds" of islands unified by geography, economy, and history. The units of analysis in Table 2 are political units treated as separate by their imperial governments. They were often unified on a larger scale than the islands of Table 1, 
Table 1. Period of Sugar Frontier by Degree of Dominance of Sugar, for Caribbean Islands

\begin{tabular}{lccc}
\hline & & Period of Frontier & \\
\cline { 2 - 4 } Sugar Dominance $^{\mathrm{b}}$ & Before 1750 & $1750-1800$ & After 1800 \\
\hline 80 percent or more & $\begin{array}{c}\text { Barbados } \\
\text { Antigua } \\
\text { Martinique }\end{array}$ & $\begin{array}{c}\text { St. Croix } \\
\text { Guadeloupe }\end{array}$ & Tobago \\
50 to 80 percent & St. Kitts & Jamaicac \\
& & Haiti \\
& & $\begin{array}{c}\text { Grenada } \\
\text { Tortola }\end{array}$ & Trinidad \\
50 percent or less & Nevis & St. Vincent \\
& St. Lucia & \\
& & Cuba & Puerto Rico \\
& & Santo Domingo
\end{tabular}

Notes: Highest Planter Economic and Social Dominance is in upper left corner.

Caribbean Islands where sugar cultivation was never important are: British in 1800s-Caymans, Bahamas, Dominica, Montserrat, Anegada, Barbuda; Dutch in 1800s-Saba, Curaçao, Aruba, St.Eustatius; Spanish and Venezuelan in 1800s-Isla Margarita; Danish in 1800s-St. Thomas, St. Johns; Swedish and French in 1800s-St. Barthélemy.

${ }^{a}$ This is an estimate of the period of highest influx of sugar planters and slaves and the highest rate of bringing new land under sugar cultivation. Where it was available, I have used the time at which the slave population was half of its stabilized value after sugar had filled its niche. For reasons discussed in the Author's Appendix, this ideal indicator was often not available, especially for the islands in the lower right of the table. Substitutes I used are discussed in the Author's Appendix.

${ }^{b}$ This is an estimate of the percentage of the labor force occupied by sugar workers and planters when the sugar labor force stabilized. Good data on this were less often available than early data on slave numbers. The substitutes I used where necessary were export data, agricultural land use data, slave/White ratios after stabilization of slave populations, or comments by travelers or residents. A low percentage indicates that there were other major agricultural crops, tree crops, or livestock, that there were relatively large urban populations, or that nothing much would grow on the island.

c Jamaica had considerable coffee cultivation and livestock raising, and a major entrepôt function, and may be misclassified.

especially when the core islands of the clouds of islands were physically smaller, less economically important, and had higher interisland distances. (This is also discussed in the Author's Appendix.)

Table 1 shows the differences in economic history of the islands that determined the degree of economic dominance of sugar planters and the timing of that dominance. It presents two causal variables; the degree of dominance of sugar in the island economy, and how long that dominance had lasted by the time I take my reading in the late eighteenth century. The dependent variable is implicit, and (as discussed above and in the Author's Appendix.) consists of the degree to which island governments devote themselves to interfering with many slave liberties in order to maximize the liberty of the slave owner to do what he or she wants with the slave. In Table 2 below, the results of Table 1 are combined with information on the form of island government to evaluate their joint effect on the dependent variable.

The length of time planters had been dominant in island government is estimated by estimating the "birth date" of planter economic dominance, which I call the "peak of the frontier period." When an island's land suitable for sugar had been devoted to other crops, converting it to sugar required an increase of the labor force of about five to ten times; this created a "frontier" period of very rapid immigration, combined with the rapid change of land from other crops or jungle to sugar. This frontier period could last from 40 years (e.g., Barbados) to 200 years (e.g., Cuba), depending on island size and heterogeneity, governmental restriction of development, and so on.

By the time half of the land to be devoted to sugar had been developed on islands that became quite completely sugar islands (and also occupied half of the labor force it would 
occupy at the end of the frontier period), about two-thirds of the population would be devoted to sugar, and around half of all sugar plantations would be run by people whose pioneering work was done and who thenceforth would be managing family estates. On islands that would end up having only half or less of their labor force devoted to sugar, such as Cuba, at the peak of the sugar frontier, only about one-quarter or less of the economic power of the island would be expected to be in the hands of planters who were managing family estates and were finished with their frontier pioneer work. During an island's frontier period, many of the planters were bachelor pioneers, many of the slaves were African, up to two-thirds of all slaves were adult males, fortunes were being made because the capital value of the plantation was being created, and in other ways an island showed demographic and economic signs of a rapid influx of people and resources characteristic of frontiers.

Thus, if the peak of the frontier, the time of most rapid influx and most rapid transition of land to sugar production, came before 1750 , by the late eighteenth century about half of all the planters had been managing family estates instead of being pioneers for about two generations and could devote themselves to developing the political and social institutions of a slave society. Fewer of the rich and powerful would be sugar-family-estate planters if sugar would never occupy most of the island or if the last half of the frontier were just being settled and family sugar estates were newly stabilized. So sugar planter social and economic dominance in the late eighteenth century should be greatest in the upper left of Table 1 and weakest in the lower right. My prediction, borne out by the informal data (described in the Author's Appendix), is that islands in the upper left of Table 1 would be more likely to have intense slave societies by the late eighteenth century, and those in the lower right would have less intense slave societies at the level of the island as a whole.

Table 2 combines the results of Table 1 (the stub runs from strong sugar dominance at the top to weak sugar dominance at the bottom, corresponding to the diagonal dimension from upper left to lower right in Table 1) with the type of local government granted to or imposed on the island by its empire in the late eighteenth century (in the heading). My final prediction is that the island units in the upper left showed signs of being "slave societies" in the late eighteenth century, and those in the lower right had governments that devoted less effort to limiting slave freedom.

The Spanish islands (which, in order of importance to Spain, were: Cuba, Trinidad, Puerto Rico, Santo Domingo, and Isla Margarita) appear in the lower right of Table 1 or in the table note, and so appear near the bottom of the stub in Table 2. In 1750, for example, the entire sugar production of Cuba was about equal to that of the small Danish island of St. Croix (MacNeill 1985:126). Trinidad, which until 1800 was a Spanish island with an infusion of French planters, also would appear in the lower right cell if it hadn't been for vigorous British development of sugar planting there after 1800 .

In the French empire, Guadeloupe and Martinique were developed earlier than Haiti. Haiti was at its maximum growth rate around 1750 or 1775 , so that its planters in the late eighteenth century were much more often bachelors out trying to get rich, and its slaves were mostly born in Africa or were first-generation creoles (i.e., born in the Americas of African parents).

In the British islands, Barbados was the first island to be developed in sugar and was dominantly a sugar island, and the Leewards were developed soon after (the Author's Appendix indicates which islands in Table 1 are grouped under the British Leewards). British Jamaica had a lot of broken terrain good for raising cattle, tobacco, coffee, or other "nonplantation" crops, but much sugar land there was developed in the middle period, before and after 1750. Jamaica was declining as a sugar plantation island by the end of the eighteenth century. Trinidad, and islands that became the British Windwards ${ }^{4}$ (Grenada, St.

4 "Windward" islands are the small islands to the east and south, conventionally starting with Guadeloupe in the northwest, but excluding Trinidad and Barbados. Around 1780, the British Windards included Tobago, Grenada, St. Vincent, St. Lucia, and Dominica. Why I classify them together here is explained in the Author's Appendix. The Appendix also describes the British Lee- 
Table 2. Factors Leading to High Planter Power: Planter Economic Dominance and Island Autonomy around 1780

Planter Representation and Island Autonomy ${ }^{\mathrm{a}}$

\begin{tabular}{|c|c|c|c|}
\hline $\begin{array}{l}\text { Planter Social and } \\
\text { Economic } \\
\text { Dominance }^{b}\end{array}$ & $\begin{array}{c}\text { (1) } \\
\text { Autonomous } \\
\text { Assembly, } \\
\text { Justice of Peace }\end{array}$ & $\begin{array}{c}(2) \\
\text { Governor- } \\
\text { Chosen } \\
\text { Council }\end{array}$ & $\begin{array}{c}(3) \\
\text { Urban Cabildos, } \\
\text { Strong } \\
\text { Bureaucracy }\end{array}$ \\
\hline $\begin{array}{l}\text { Bachelor adventurer- } \\
\text { planters or other } \\
\text { crops prevalent }\end{array}$ & $\begin{array}{l}\text { Jamaica } \\
\text { Surinam }\end{array}$ & $\begin{array}{c}\text { Br. Windwards } \\
\text { Haiti } \\
\text { Guyana } \\
\text { St. Croix }\end{array}$ & Trinidad ${ }^{c}$ \\
\hline $\begin{array}{l}\text { Few planters, } \\
\text { many ranchers, } \\
\text { peasants, merchants }\end{array}$ & Curaçao & $\begin{array}{l}\text { Dominica } \\
\text { Bahamas } \\
\text { St. Thomas }\end{array}$ & $\begin{array}{c}\text { Puerto Rico } \\
\text { Santo Domingo } \\
\text { Cuba }^{\mathrm{c}}\end{array}$ \\
\hline
\end{tabular}

Note: Planter power is highest in the upper left corner.

${ }^{a}$ Autonomy and control over administration of the law led to high planter power (column 1), urban representation and strong bureaucracy led to low planter power (column 3). The classification is impressionistic, and I have considered factors not mentioned in the table showing high island power in empire policy as applied to the island. (See the Author's Appendix.)

${ }^{b}$ When there were fewer planters and when they were birds of passage developing a frontier and did not form local families to use power consistently (when they were "bachelor adventurer planters") then planter power was low. If settler planters dominated the economy on the islands where they had great organizing capacity developed over historical time, they had greater power. See the discussion of Table 1, which is collapsed diagonally to produce the stub of this table. (See also the Author's Appendix.)

c Cuba, taken as a whole, was never dominated by sugar cultivation, and Trinidad was not dominated by sugar in 1780 , but was being settled rapidly by French planters under a Spanish government. Both had politically powerful sections dominated by sugar in the nineteenth century, and most of the literature on slavery on those islands deals with that period. Cuba never had as much as 50 percent of the labor force in sugar. In the late eighteenth century, Cuba and Trinidad were not as different as indicated by their different placement in the table.

Lucia, St. Vincent, and Dominica), were developed later, as was Guyana, which was economically and socially an island, although not geographically so. Much of the development of these colonies took place after England abolished slavery and so much of the development of new sugar land was done by indentured East Indians rather than by slaves. But looking at these islands in the late eighteenth century, planters were not yet in a position to develop a thoroughgoing slave society, even if England had been in a mood to let them.

ward islands; the core ones are Antigua, St. Kitts, and Nevis. Exactly which islands were included in these groups varied historically for the reasons discussed there, and the groupings were different in different languages.
But planters could organize their economic power into class power if they had extensive ties with each other, had much time to shape institutions to their liking, had established households and were looking to the longterm health of their class and its wealth. The extensive apparatus of slave society that was imported into South Carolina from Barbados (Jordan 1969:84-85), or that is so beautifully documented in the legal studies of Goveia ([1965] 1980) on Antigua and the other British Leeward Islands, was not quite as developed in Jamaica and was much weaker in Trinidad, Grenada, or Guyana. Thus the result of Table 1 (summarized in the vertical dimension of Table 2) is that the island governments in the top row should be more dominated by sugar planters, and thus more devoted to restricting slave liberties. 
Table 2, then, combines into one dimension the two sources of planter domination of the economy and society of each island in Table 1, and adds a dimension that measures the powers granted to local legislatures by the empire. Local authorities, dominated by planters when there were many of them, were more powerful when they had an assembly to which they were elected (column 1), rather than a cabinet of the governor to which the governor appointed the local rich (column 2), and these were more powerful than urban cabildos with small powers dominated by a strong Spanish bureaucracy (column 3). The same amount of planter dominance (in the stub of Table 2) translated into more governmental power (column 1) than occurred in column 2 , in which a governor might consult with planters of his own choice, and into least power in column 3. In general in the English colonies with powerful legislatures, the main agents in small localities were volunteer "gentry" justices of the peace, so implementation of laws was in the hands of planters.

At the opposite extreme were the Spanish colonies (again Cuba, Trinidad, Santo Domingo, Puerto Rico, and Isla Margarita), where the local councils were the cabildos of cities, where most legislation governing the colonies was not passed by such cabildos, but instead by the Council of the Indies in Spain, and where the implementation of all laws was in the hands of civil servants, "peninsulares," sent out from Spain. Planters had to apply to the cabildo for permission to turn their cattle ranches into sugar plantations (Riverend 1972:111-12, 119-20; Marrero 1978:15).

Thus, in the upper left of Table 2 are the islands where both demography and the structure of local government in the empire maximized planter power. Barbados was the high point of planter power and had the fullest development of slave institutions, the greatest devotion to limiting slaves' liberties (and free colored liberties as well), and an inclination to defy the colonial office soberly and effectively, claiming imperial power for its own. Jamaica, Surinam, the British Leewards, Martinique, and Guadeloupe were close competitors with Barbados.

The lower right of the table is dominated by the Spanish islands that Klein (1967) used to illustrate the relative softness of Caribbean slavery, ${ }^{5}$ the entrepôt islands of the Danes and the Dutch, and many miscellaneous small non-sugar islands that did not have much autonomy and that I left out of Table 2 as unimportant.

Slave societies, then, were created when the dominant people were those to whom slavery in its most extreme form was desirable; in the eighteenth-century Caribbean these were sugar planters. Three main factors made them dominant: (1) sugar as a large proportion of the economy, (2) a planter aristocracy with a solidary style of life in which managers of family estates had an interest in slave institutions, (3) and empires that let planters run island government. These served as multipliers of slave institutions, making them more elaborately oppressive. On the other hand, on the Spanish islands and Dutch islands (only Dutch Curaçao and the Dutch "island colony on the coast," Surinam, are important enough to mention in Table 2) there were very few records of and regulations about manumissions, but very many free colored and free Black people. Most records of free Blacks and free colored people on Spanish islands are apparently based on censuses that asked them whether or not they were free. This was very much a nonslave-society way of finding out who was free, and indicates a low level of government interest in pushing slavery to its extreme.

\footnotetext{
${ }^{5}$ Klein (1967) compared Virginia, dominated by tobacco rather than cotton and so one of the softest slave regimes in North America (but with well-organized planters), with Cuba, where the region around Havana and Santiago de Cuba had some of the tough slavery of resident planters in the sugar islands, and the other regions had the very soft slavery of peasant farming with little rural access to the levers of power in the empire. Knight (1970) tried to refute Klein, but he looked only at the small sugar part of the only serious Spanish sugar island and at the internal system within the plantations rather than at planter success in instituting governmental limitations on the options of blacks and free colored people. None of the places compared in this literature resembled Barbados, Antigua, or South Carolina in the degree to which they were slave societies. The political situation of Cuban planters was changing very rapidly in the late eighteenth century (Kuethe 1986). Scott (1985) offers a good overview of this whole debate.
} 


\section{EXPLAINING WITHIN-ISLAND VARIATIONS IN SLAVERY: SLAVES AS AGENTS}

The liberty of planters to deal with slaves as they liked meant that slave owners could make whatever deals they liked with the slaves. Often owners used such liberty to make contracts that look like those made with free people, except that one of the rewards was sometimes manumission. Manumission was in some sense often a "career" reward, the last promotion for a faithful and loyal slave. Like many such rewards in bureaucratic organizations, one does not know whether one gets the final reward until near the end of one's career. One should then expect to find manumission in the same sorts of places in the economy we find bureaucratic promotions and generous pension schemes in modern society-where long and skilled service showing loyalty, discretion, and good faith were required by the economic task.

Other features of the agency contract of modern civil law appear in the lives of some slaves. Contracts in which the principal (the person who "hired" the slave, in this case the slave owner) monitored the outcomes of slave (agent) behavior rather than supervising the behavior closely, granted much discretion to agents, rewarded the agent in proportion to outcomes, and delayed agent reward until the overall results were in, were rather like those between a house owner and a real estate agent in modern society. According to modern agency theory, in situations where the agent has more information and more control over effort, enthusiasm, and intelligence than does the principal, such contracts are thought to achieve the principal's purposes better than would close supervision. I argue that treating slaves as almost free, and sometimes eventually as legally free, in the eighteenth-century Caribbean was usually an agency contract. Such contracts solve the problem of trust between slave and master better than coercion does. Except in the case of sexual relations, such agency contracts reduce supervision costs. In the extreme, when the slave owner would have had to be on the sea bottom watching the slave collect pearls off Isla Margarita, the cost of supervision would exceed the total value of the slave's labor. At the other extreme, supervising cane holing with a whip is cheap and effective.

\section{Coercion, Norms, and Social Ties in the Formation of Race}

Coercion was central to creating the slave population of the Caribbean and determining its racial composition. It was because coercion could be and was applied by White Europeans to Black populations in west Africa, and could not be or was not applied as intensively in Europe, that the labor demand in the Caribbean was translated into an African slave population. Coercion, rather than reward, dominated labor relations in the Caribbean, especially in the core of the slave system, the sugar plantation.

The totality of the definition of the coercive relation was greatest in the islands in the upper left of Table 2, least in the lower right. But people define the meaning of such larger coercive and normative structures, even like those in the upper left, in the course of daily activity. What owners wanted out of slaves depended on the activities they were trying to carry out by means of the slaves. The sexual tie was probably the most important one modifying slavery in the direction of freedom in the late eighteenth century. A number of other relations between powerful Whites and slaves modified the use of coercion and the use of class-conscious planter normative definitions in daily life.

Unfortunately, negotiations between slave and master rarely appear in the historical record. Slaves had no right to appeal in court, had few or no property rights defended by the courts, could not sign legally enforceable contracts, did not pay taxes, were maintained illiterate by social policy, and were not regarded as objects of religious institutions that kept records. So the problem here is quite different from finding out about variations in government action between islands, as I have done above; here I want to distinguish among individual slaves within an island society according to their ties with masters.

Five main conditions generated records bearing on the daily lives of slaves and slave-master relationships. One was manumission, the establishment of a former slave as free by a governmental act initiated by the owner. Documents about the conditions 
of such manumissions often tell something about the relations between slaves and masters under various conditions, although slave societies generated more manumission documents per free Black person than did societies whose central institution was not slavery. (This is discussed further in the Author's Appendix).

A second source was records of emancipation, the proposal by governments to treat slaves as free people whose rights needed to be documented to be defended. Closely related was the abolition of the slave trade, which created the category of illegally imported (and therefore legally free) slaves, who had to be distinguished from legitimate slaves. The documents telling which categories of the emancipation law which slaves fell under often tell something about the relations of slave to free.

A third source of records about slave-master relations was plantation accounting books and other plantation books of well-run plantations or other slave enterprises. The value of a slave depended in part on the nature of his or her activity, and so activities and special arrangements were recorded.

Fourth, governments had military or political reasons to treat some slaves (or former slaves) differently than others, especially if they had had military training and experience, had been to the mother polity and so had a claim to freedom, belonged to powerful maroon (runaway rebel) groups in the interior, or otherwise had a distinctive relation to the coercive or normative system defining slavery. A troop of Black soldiers obviously presented a different coercive problem than a gang of fieldhands. ${ }^{6}$

Finally, some churches administered some religious activities that bore on the daily lives of slaves, especially on their marriages, births, and deaths.

All of these sources are irregularly available. Religious records of marriages and baptisms are much more available in the Catholic empires (Spanish and French) than in the Protestant ones (English, Dutch, and Danish). Records generated by the enforcement of the abolition of the slave trade are prima-

\footnotetext{
${ }^{6}$ See Geggus (1982:315-25) for details on how the British thought about Black and colored troops in Haiti during the British occupation.
}

rily available for the English islands, forming, for example, the basis of Higman's marvelous demographic analysis of slavery in the early nineteenth century (1984), because only there was the imperial government really behind abolition of the trade.

In what follows, I develop a thesis about how the need for slave agency increased the freedom of slaves. I examine the five kinds of data above, especially looking at what groups of slaves were most likely to be manumitted. My thesis, by necessity, draws also on my speculations about the facts underlying these patterns; one might say that I follow the "theoretical method," discredited in the discipline of history, in which "theory" involves, in part, guessing at the facts. I go now to the theory, presented primarily as a theory of manumission rates.

Slaves had to form a relationship with owners or other powerful people in order to be freed. It was of course simplest to form a relationship with their own owners, and to persuade them (see note 3 ) to give them freedom, either as a gift or by testament on the owner's death. Sometimes ties to free people other than masters could become indirect ties to their owners, as when another free person bought slaves for the purpose of freeing them. Relationships to White employees of the owner, for example, fairly often resulted in freedom, with the employee buying the slave or being given the slave by the owner in appreciation for long service (Cauna 1987:134-35).

To understand why slave liberties might depend on the sort of tie between owner and slave, I must explain how planters' ties to colored and Black creole and African slaves varied: Creole slaves were freer and were more often manumitted. Ties also varied between small and large slave holdings: Slaves were more often freed on small holdings. Ties varied between city and plantation: Urban slave owners freed slaves more often. Ties varied between colonies in which sugar planting was rapidly expanding and older colonies where sugar had filled its niche: Older colonies had denser ties but more developed slave societies. Ties varied over time with the political situation: The French revolution and the abolition campaign in England, for example, substantially increased manumissions. Ties varied between 
empires: English planters were the least liberal in giving liberties to their slaves (even though they were least constrained by their home governments); the French were somewhat more likely to free slaves and to treat them as they treated free people; the Dutch and Danish were more liberal yet, though slave owners' liberties were very little restricted; and the Spanish (to exaggerate) used slavery mainly to recruit immigrants, and after immigration slaves were often informally freed and managed by those means the Spanish colonial government and powerful people used to manage "free" labor.

The evidence I examined showed that these are the variables that shaped rates of manumission, so they must have been the variables that determined the sorts of ties slave owners had with slaves. By extension, these variables must have shaped ties slave owners had with people they had just freed, and so determined the meaning in daily life of the boundary between slave and free.

Besides the powers of property, there were also powers of governments on the islands; ties of slaves to those powers could also result in freedom. When slaves rendered military service, especially during slave revolts, or against maroons or foreign invaders, the government often freed them for their loyal service and reimbursed their owners.

Both France and England in the seventeenth century had explicit arrangements that slave ownership could not be enforced in the mother polity. Thus, slaves automatically became free if they got to Europe. But, at least in France, these arrangements were substantially modified in practice over time so that slaves could be brought into the mother polity under various special dispensations that preserved their slave status while in France (Peytraud 1897:373-400).

Sometimes treaties with rebels in the colonies (either White rebels with slave recruits, or slave or maroon rebellions) granted freedom. Quite often owners were not reimbursed; the presumption must have been that if it required great state expense and activity to enforce slave ownership, reimbursement was not an obligation of the state.

The general point is that legal freeing of slaves required slave access to power, either the power of the owner or the power of the government. The power of property in slave society was particularly oppressive, but that oppressiveness gave property owners great discretion to define what ownership meant for particular slaves. No contract or law guaranteed equality of treatment, so some could be freed and others kept slave without violating property rights.

To understand what the boundary between slave and free meant socially, then, I interpret the data on manumission in terms of what sorts of ties could produce freedom. Manumission is the extreme form of stratification created by planter will within the slave community, which made some slaves able to make claims on (or against) White power holders and which left freed people who had "only barely" been freed unable to claim the full rights of citizenship (insofar as there were rights so universally available that they could be called "citizenship").

\section{Four Forms of the Slave-Master Agency Tie}

Slaves had four main ways to form ties with White people that might result in freedom: sexual and other intimate ties, agency in cooperative work (domestic work and and management), commerce, and politics.

Sexual and other intimate ties. Sexual ties between slave and free were mostly between White men and Black or colored slave women, especially young, creole, colored, domestic servants (of course, slaves might become domestic servants because of sexual selection, rather than be sexually selected because they were domestic servants). Peytraud (1897) quoted a letter from two island authorities about the ties between White male lovers and their Black or colored mistresses:

If we did not take care to stop the manumission of slaves, there would be four times as many as there are, for here there is such great familiarity and liberty between masters and negresses, who are well formed, which results in a great quantity of mulattos, and the most usual recompense for their obliging compliance to the wishes of the masters is the promise of liberty which is so gratifying that, together with their sensuousness, the negresses determine to do everything their masters wish. (Peytraud 1897: 409)

Of course this causal analysis is a "Just So Story," because it does not explain what a White male needed the consent of his slave 
for. It is clear that in such a coercive relation as that of master to slave, rape could as easily be part of the daily routine as seduction. The master had to promise something only if he wanted something more than a rape relation to his sexual partner.

Like enthusiastic work, enthusiastic voluptuousness was not easily elicited by typical slave master coercion. The statistical fact that the above letter tried to explain-that mistresses of owners were much more likely to gain manumission-was, however, there to be explained.

In self-reproducing free colored populations the sex ratio (ratio of males to females) tended toward a normal one. However, in the slave societies in which most free colored had been manumitted, the free colored sex ratio showed a very high ratio of women to men. For instance, Laurence (1983:40) gives the sex ratio for Tobago in 1790 among free colored with origin among the British slaves as a little over 2 women to 1 man or about .5 , among those with origin among the French slaves a little over 3.5 women to 1 man or about .3. Most of the free colored in Tobago at that time must have been created by manumission, because this was very early in sugar development there.

For most English colonies there are also more direct data on manumissions themselves.

[Slaves manumitted] tended to be female, creole, young, and colored, and to work as domestics. In the sugar colonies females were roughly twice as likely to be manumitted as males in the period before 1820 , but this difference narrowed significantly in many colonies as emancipation approached. ... Females, however, more often obtained manumission through sexual relationships with Whites or freedmen, and such relationships were by no means confined to the towns. (Higman 1984:383)

The children of such unions had an indirect sexual tie with White power. The patriarchal and "blood" ideology of European families in the eighteenth and nineteenth centuries reinforced these indirect sexual ties, though that ideology also downgraded blood ties for resulting from sexual relations outside marriage, and even more for "miscegenation." Manumissions of Whites' own colored children were indirectly sexual, or "paternal."
Presumably sexual and paternal ties would have more effect when they lasted longer. Family-like relationships between settled Whites and their lovers and children would tend to produce more egalitarian relationships between the couple and in the paternal relationship, and thus to result in manumission. Sexual ties with domestic slaves and with slaves on small farms would then tend to result in more manumissions.

Clients of slave prostitutes would probably rarely be involved in their manumission, but ties between owners and their prostitute slaves might result in commercial manumission as discussed below. Note that the manumission of mistresses because one wants honest love is not strictly the sort of agency analyzed in modern economics, as was the incentive system under which the prostitute apparently worked for her owner. The reasons why one does not want to elicit affection with threats of whipping at each step and why rape of slaves did not create manumissions the way concubinage did are deeper than agency theory in economics explains. The causes of wanting slaves to make "free" affectional decisions and granting eventual freedom are apparently the same.

Some evidence indicates that the strength of sexual and paternal bonds may be higher when the owners and slaves are racially more homogeneous:

In Bridgetown, where freedman slave ownership was concentrated, 2.6 percent of the slaves owned by freedmen were manumitted between 1817 and 1820 , compared to only 1.0 percent of those belonging to Whites. In rural St. Michael these percentages were 1.2 and 0.2 respectively. Thus, slaves of freedmen were two to three times more likely to be manumitted than those of Whites, both in town and in the country .... [T] he highest manumission rates occurred where freedmen were already relatively numerous, for example in Trinidad, St. Lucia, the Virgin Islands, and the Bahamas. (Higman 1984:385)

Manumission of young women, then, can serve as a tracer of intimate relations between master and slave that tended toward love rather than rape or prostitution. Manumission of children of mistresses can serve as a tracer of those relations between master and slave children that tended toward paternity rather than breeding. 
Agency in cooperative work. By agency in cooperative work, I mean domestic and managerial ties-ties that involved close continuing contact between a White slave owner (or owner's wife or agent) and a slave who must be trusted to achieve objectives that could not sensibly be monitored as "gang labor." Domestic servants who were not sexual partners were more likely to be manumitted than field hands. Slave drivers, mechanics, and stockmen were freed more often than were less skilled slaves. Slaves were selected into these groups by skill and loyalty.

These groups were disproportionately creole and colored. For example, "by 1834 at least 60 percent of slave domestics in Jamaica were colored, compared to 10 percent of the total slave population" (Higman 1983:126). Having been exposed to European culture, creole colored people could communicate effectively with the master and carry out the "agency" with an understanding of the owner's purpose. Such relations established an "unequal colleagueship" between master and slave, sentimentally and morally closer than that in a field gang. Agency relationships were based on cultural similarities that produced trust and fellow-feeling. Agency often required the owner to set up an incentive system more like an employment contract than a slavemaster relation. Such contracts often led the owner to conceive of the slave as having rights to the reward promised, as well as obligations. Among those rights could be the right to freedom.

Domestic slaves were generally much more likely to be manumitted than were field slaves. For example,

[I]n St. Lucia in 1815-19 . . only 11 percent of the slaves manumitted were field laborers, although they accounted for 44 percent of the slave population. On the other hand, 52 percent of those manumitted were domestics (17 percent of the population) and 15 percent were tradesmen (5 percent of the population). (Higman 1984:384)

The ratio of the probability of manumission of domestics to the probability for field laborers was about 12 to 1 , and about the same for tradesmen compared to field hands. Some of the higher probability of manumission for domestics was sexual, but a good deal of that advantage was preserved for domestic slaves of female owners.

Slaves on smaller rural holdings were also more likely to be manumitted. Furthermore, in those Spanish islands in which slaves often worked in large ranching enterprises before the sugar boom of the late eighteenth and nineteenth centuries (Cuba, Santo Domingo, and Puerto Rico) the rate of manumission was much higher, as reflected in a large free colored population (few manumission documents exist, as is explained in the Author's Appendix). This may be due to the impossibility of supervising cowhands in gangs and the damage that can be done to valuable animals by carelessness. If so, these conditions would have produced more "employment-like" relations between the rancher and his or her agents than was true on sugar islands (Boin and Serrule Ramúe [1979] 1985:61, 63).

Commerce. I define commercial ties as master-slave relations whose basic form was the exploitation of the slave by a formal contract with the slave, similar to the institution of obrok in Tsarist Russia, though such contracts were not legally valid. The contract was generally one in which the slave exploited commercial opportunities at his or her own discretion. Women carried on huckstering enterprises in the market; men hired themselves out for episodic transportation work on the docks; women were prostitutes; both sexes manufactured goods; women provided laundry services for hire. The commercial opportunities available to slaves were mostly located in urban areas.

These opportunities could not easily be monitored, so the owner needed a contract with the slave to encourage the slave to seek out opportunities. The better the owner's monitoring, the higher the owner's share of the return. Slave prostitutes were often owned by female entrepreneurs, often free colored women, and often presumably exploited the commercial opportunities in a house maintained by their owners (see the painting in Hoyos 1978:170).

According to agency theorists (e.g., Heady 1952), agents with control over information and effort required a contract in which the agent (slave) collected most of the marginal product of his or her exploitation of those opportunities. Further the contract had to give 
rights to the agent (the slave), so the owner could not change the terms and claim the whole product. On eighteenth- and early nineteenth-century plantations, the owner claimed the whole marginal product, which is why production had to be organized as highly monitored "gang labor."

Thus, the optimum contract in such circumstances (i.e., where continuous monitoring is difficult or expensive) is one in which the agent (slave) pays a fixed rent for the use of the asset (the farm in farm tenancy, the Russian serf in obrok, the slave in urban huckstering) and takes the whole product of the commercial activity. This way, the person who has the most information about opportunities and whose effort and attention determines the profitability of exploitation of those opportunities collects the full marginal product of the exploitation and therefore is strongly motivated, even in the absence of supervision (Heady 1952). Such a situation tends to create rights for the slaves that the owner feels bound to respect and that give slaves money to buy themselves out of slavery.

This explains why African slaves in cities had high rates of manumission, whereas in other locations Africans had the lowest manumission rates. Urban African slaves were disproportionately males on the docks, working in a system that must have been much like the "shape up" in longshoring on the American East Coast (Bell [1954] 1993). Stevedoring entrepreneurs or merchants or ship captains - the loading was apparently normally actually managed by the mate or maître-needed strong men for casual labor on an episodic basis. Urban male slaves were uniformly more likely to purchase their freedom than any other group (Higman 1984: 382). A similar mechanism of wanting intense work for a while and then to get rid of the worker might explain why houses of prostitution did not own many old women.

Before the twentieth century, commercial relations were much more dominant in cities than in the countryside. Furthermore, there was not much gang labor in simple tasks requiring little skill and initiative in cities in the late eighteenth century. Much manual labor in pre-modern cities was carried on by independent artisans, and much of the rest of it was casual wage labor or piecework labor in temporary jobs. Permanent relations between the people who wanted the work done and those who did the work were not the normal way of organizing work in cities in the eighteenth century. The same forces that produced free-labor-contract incentive systems for free urban manual laborers would have tended to produce the same conditions for slave laborers in cities as well.

Politics. Finally, the slave's political services that led to freedom were largely military and police services. The more sugar was dominant on an island, the fewer Whites there were to defend the island, and the more valuable it was to an empire. Islands largely devoted to sugar such as Haiti, Martinique, Guadeloupe, and Jamaica were therefore militarily vulnerable and commercially valuable in the frequent wars of the seventeenth and eighteenth centuries. Islands were less vulnerable if their governments could recruit colored people and Blacks to defend them.

For example, Guadeloupe was less conquerable than Martinique in the wars between England and France in the 1790s. Guadeloupe had freed its slaves and recruited both Black and colored troops into the militia, and after a precarious conquest the British failed to hold or reconquer it. Martinique, which had not freed slaves or recruited colored troops extensively, was fairly easily conquered. Napoleonic France did not actually reconquer Guadeloupe, but rather the colored general (Malgloire Pélage-see Bangou 1989) at the head of the troops switched allegiance to the empire government.

Sometimes treaties with organized rebel or runaway Blacks were forced on colonial governments. For example, after a war in Surinam between the Dutch and maroons ("bush negros"), the French in Guiana agreed with the organized Blacks that they could settle as free negroes ("de les établer comme des nègres libres et les contenir sur ce pied," literally, settle them as free Blacks and restrain them on that footing [Peytraud 1897: 358-59]).

The empires had a great deal of trouble with military operations in the Caribbean because troops from Europe quickly became too ill to fight. Planters tended to form militias that were not reliable servants of the empire, but instead formed alliances with whoever would best defend planter interests. 
Table 3. Factors in Manumission Rates

\begin{tabular}{|c|c|c|}
\hline Causal Process & Examples & Categories Most Likely to Be Manumitted \\
\hline \multirow[t]{2}{*}{ Sexual and other intimate ties } & Sexual partners & $\begin{array}{l}\text { Young, creole, }{ }^{\mathrm{a}} \text { colored, }{ }^{\mathrm{b}} \text { women domestics } \\
\text { Women on small slaveholdings } \\
\text { Women owned by free colored people }\end{array}$ \\
\hline & Colored offspring & $\begin{array}{l}\text { Creole, colored, domestics, young slaves } \\
\text { Children in stable relationships }\end{array}$ \\
\hline \multirow[t]{3}{*}{ Agency in cooperative work } & Slave drivers & Male, creole, middle-aged \\
\hline & Skilled & Male craftsmen, mechanics, artisans \\
\hline & Domestics & Women, household domestics, nannies \\
\hline \multirow[t]{3}{*}{ Commerce } & Dock workers & Male, African \\
\hline & Prostitutes & $\begin{array}{l}\text { Colored urban women } \\
\text { Slaves owned by females (often colored) }\end{array}$ \\
\hline & Hucksters & Creole women \\
\hline Politics & Military and police & $\begin{array}{l}\text { Young males } \\
\text { Militia members } \\
\text { Maroons }\end{array}$ \\
\hline
\end{tabular}

a "Creole" here means born in the Americas, as it is used in the British islands. In Spanish the comparable word implies White race; in Louisiana it means of French origin.

b "Colored" sometimes referred to people of mixed (African and European) race, especially when speaking of slaves. However, in some situations a manumitted slave, whether of mixed descent or exclusively African, might be referred to as "free colored," as would the children of such a slave.

Planters also sponsored independence movements if it was proposed to tax them to support the defense of the empire (for Haiti, see Frostin 1975). The empire's military officers needed "seasoned" (i.e., immune to diseases prevalent in the Caribbean) troops from the islands themselves, but who would be more deployable than the local militias. Free colored and slaves were often used for building fortifications and other nonfighting military work, and sometimes for international fighting. Sometimes they were used as "intelligence agents" to find out about rebellions or to hunt down runaways. In any of these cases, they might be freed for their political services.

\section{The Boundary between Slave and Free}

In daily life, then, the most oppressive slavery occurred among field laborers on the large, highly class-conscious, and oppressive sugar plantations. Hardly any sugar plantation field workers were manumitted; few had intimate relations with Whites, though they sometimes got pregnant in nonintimate relations; few managed work on a collegial basis with the owner or owner's agents; few sought commercial opportunities with autonomy and discretion; few earned freedom from governments as a reward for loyalty and bravery; and all were subjected to the most class-conscious slave owners, those most interested in the "health" of the slave system as a whole.

As this sugar plantation core of slave society sloped off into slave mistresses or slaves owned by freedmen, creole slaves in domestic service, slaves in skilled work or first-line management, slaves in cities and especially in urban commerce, slaves in smaller enterprises, slaves of masters to whom the maintenance of the whole slave system was a secondary consideration, the master-slave relation became more like the relations among free unequal in eighteenth-century urban society. And that slope also led to the boundary between slave and free colored. A few people at the high-freedom end of these slopes in fact became free colored or Black freedmen. If they were women, they maintained the free colored population thenceforth, because the children of free colored women were also free. With the exception of reconquered Guadeloupe, there were no large movements of free colored people back into slavery. 
Table 3 presents these patterns of manumission rates. I argue that the causal processes shown in the stub of the table were different kinds of ties between master and slave-processes that required discretion, loyalty, enthusiasm, skill, career training, or other aspects of agency relations. These causes, then, explain high manumission rates, and by inference, therefore, other ways in which slaves were treated more nearly as free.

\section{CONCLUSION}

The sociology of slavery and freedom has been crippled by not treating freedom as a continuous variable. Freedom is often thought of as a legal concept, as for example that defined in the Bill of Rights of the United States, so it is either guaranteed or not. The size of the set of possibilities among which a group of people chooses-the core idea of freedom here-is clear enough conceptually but hard to specify in practice because possibilities not chosen do not leave a historical record. My intellectual strategy has been to specify freedom by its causes, the causes of more and less restriction on slaves' choices in the late eighteenth-century Caribbean. These causes fall into two main groups: (1) the causes related to the power in island societies that was held by sugar planters, who had a great interest in restricting slaves' liberties, and (2) the causes related to the use by slave owners of their property rights in making agency contracts with their slaves. The scattered evidence of what slaves and their owners in fact chose (such as manumission of the slave), or of what slaves could choose (such as how to spend their wages), or of what property rights slaves had (such as having enough money to buy freedom), suggests the shape and size of the set of possibilities under different causal conditions.

What was generally distinctive of the eighteenth-century Caribbean colonies of all the empires (as of the American South at the same time) was the building of slave societies, societies whose principal governmental problem was holding slaves in bondage of varying degrees of restrictiveness. But the intensity of governmental effort to restrict possibilities, the degree of enforcement of oppressiveness of slavery, was greater where planters were more economically dominant, had better class unity, and were well represented in the system of government of the islands in the relevant empire.

But within a given level of slave society (in this case, low), an Isla Margarita pearl diver who had to risk his life under the water, where his owner could not monitor the work without risking his own life, presented a different control problem than did a gang worker digging holes for planting sugar cane. So within the Spanish empire, slavery in the region near Havana in Cuba resembled that in Jamaica, while slavery in Isla Margarita resembled that in the Bahamas. This occurred because fishing off the Bahamas was more nearly like the agency problem of pearl diving than like the agency problem of getting more dirt moved by a gang of recent African immigrant slaves in either Havana province or Jamaica.

As a practical matter, a thoroughgoing slave society was a utopian vision by planters, but in many situations they could not get from that vision what they wanted out of real slaves. The more their society resembled that in Barbados, the easier it was to get work done at low cost on their sugar plantationsbut the harder it was to get the slaves to look after the livestock carefully or to harvest fish from the Caribbean, and the more salted fish they had to buy from New England. The more their society resembled that in Curaçao, the more easily they could send their slaves off as their agents on business or household matters. But in either kind of society, those slave owners who wanted commercial trustworthiness, initiative, courage, enthusiasm, or love, had to grant the slave enough freedom to be able to make deals with elements of equality and choice in them. Absolute power may have corrupted absolutely, but it had the additional disadvantage that it would not get the pearls off the bottom.

ARTHUR L. STINCHCOMBE is writing a book on The Political Economy of the Caribbean from 1775 to 1900. He is thinking about retiring so he can get some work done; advice is welcome.

\section{REFERENCES}

Bangou, Henri. 1989. La revolution et l'esclavage à la Guadeloupe 1789-1802: Épopée noir et génocide (Revolution and Slavery in Guadeloupe 1789-1802: Black Epic and Genocide). Paris, France: Messidor/Éditions sociales. 
Bell, Daniel. [1954] 1993. The Racket-Ridden Longshoremen. New York, NY: Irvington.

Boin, Jacqueline, and José Serrule Ramúe. [1979] 1985. Processode Desarrollo del Capitalismo en la República Dominicana 1844-1930 (Process of Development of Capitalism in the Dominican Republic 1844-1930). 3d ed. Santo Domingo, Dominican Republic: Graniel.

Cauna, Jacques. 1987. Au temps des isles à sucre: Histoire d'une plantation de Saint-Domingue au XVIIIe siècle (In the Time of the Sugar Islands: History of a Plantation of Haiti in the Eighteenth Century). Paris, France: Éditions Karthala et A.C.C.T.

Commons, John R. 1924. Legal Foundations of Capitalism. Madison, WI: University of Wisconsin Press.

Frostin, Charles. 1975. Les révoltes blanches à Saint-Domingue aux XVIIe et XVIIIe siècles (Haòti avant 1789) (The White Revolts in Saint-Domingue in the Seventeenth and Eighteenth Centuries [Haiti before 1789]). Paris, France: L'École.

Geggus, David Patrick. 1982. Slavery, War, and Revolution: The British Occupation of Saint Domingue, 1793-1798. Oxford, England: Clarendon.

Goveia, Elsa F. [1965] 1980. Slave Society in the British Leeward Islands at the End of the Eighteenth Century. Westport, CT: Greenwood.

Heady, Earl Orel. 1952. Economics of Agricultural Production and Resource Use. New York: Prentice-Hall.

Higman, Barry W., ed. 1984. Slave Populations of the British Caribbean 1807-1834. Baltimore, MD: Johns Hopkins University Press.

Holt, Thomas C. 1992. The Problem of Freedom: Race, Labor, and Politics in Jamaica and Britain, 1832-1938. Baltimore, MD: Johns Hopkins Press.

Hoyos, F. A. 1978. Barbados: A History From the Amerindians to Independence. London, England: Macmillan Education Limited.

Jordan, Winthrop D. 1969. White Over Black: American Attitudes Toward the Negro, 15501812. Baltimore, MD: Pelican.

Klein, Herbert S. 1967. Slavery in the Americas: A Comparative Study of Virginia and Cuba. Chicago, IL: University of Chicago.
Knight, Franklin W. 1970. Slave Society in Cuba During the Ninteenth Century. Madison, WI: University of Wisconsin Press.

Kuethe, Allan J. 1986. Cuba, 1753-1815: Crown, Military, and Society. Knoxville, TN: University of Tennessee Press.

Laurence, K. O. 1983. "Tobago and British Imperial Authority, 1793-1802." Pp. 39-56 in Trade Government and Society in Caribbean History, 1700-1920, edited by B. W. Higman. Kingston, Jamaica: Heineman.

MacNeill, John Robert. 1985. Atlantic Empires of France and Spain: Louisbourg and Havana, 1700-1763. Chapel Hill, NC: University of North Carolina Press.

1978. Cuba: Economía y Sociedad. Vol. 7: Del Monopolio Hacia la Libertad Comercial (1701-1763), del II (Cuba: Economy and Society. Vol. 7: From Monopoly to Commercial Liberty [1701-1763] part II). Madrid, Spain: Editorial Playor.

Moreno Fraginals, Manuel. [1964] 1976. The Sugarmill: The Socioeconomic Complex of Sugar in Cuba 1760-1860. Translated by C. Belfrage. New York: Monthly Review Press.

Naipaul, V. S. [1969] 1984. The Loss of Eldorado: A History. New York: Vintage Books.

Patterson, Orlando. 1967. The Sociology of Slavery: An Analysis of the Origins, Development, and Structure of Negro Slave Society in Jamaica. London, England: MacGibbon and Kee. 1991. Freedom. Vol. I: Freedom in the Making of Western Culture. New York: Basic Books.

Peytraud, Lucien. 1897. L'Esclavage aux Antilles Françaises (Slavery in the French Antilles). Paris, France: Librairie Hachette.

Riverend, Julio le. 1972. Historia Económica de Cuba (Economic History of Cuba). Barcelona, Spain: Ediciones Ariel.

Scott, Rebecca Jarvis. 1985. Slave Emancipation in Cuba: The Transition to Free Labor, 18601899. Princeton, NJ: Princeton University Press.

Tannenbaum, Frank. 1946. Slave and Citizen: The Negro in the Americas. New York: Vintage.

Williams, Eric. [1944] 1964. Capitalism and Slavery. London, England: Andre Deutsch. 